\title{
Hospital Utilization Trends in Selected New EU Member States
}

\author{
A. Dietrich (Alexander Dietrich)1, V. Foltin (Viktor Foltin) ${ }^{2}$, \\ D. J. West Jr. (Daniel J. West Jr. $)^{1,3}$
}

${ }^{1}$ The University of Scranton, Department of Health Administration

Original Article and Human Resources, 417 McGurrin Hall, Scranton, PA-18510, USA.

${ }^{2}$ St. Elisabeth University Bratislava, Dept. of Public Health, P.O. Box 104, 81101 Bratislava, SK.

${ }^{3}$ Panuska School of Professional Studies, NOS, Scranton, PA USA.

\section{E-mail address:}

daniel.west@scranton.edu

\section{Reprint address:}

Alexander Dietrich

Univ. of Scranton, Dept. of Health, Scranton

PA 18510

USA

Source: Clinical Social Work and Health Intervention

Volume: 11

Issue: 2

Pages: $12-18$

Cited references: 14

\section{Reviewers:}

Roberto Cauda

MD PUD CUSH Rome, Italy

Gabriela Lezcano

UOSF San Francisco, CA, USA

\section{Keywords:}

Hospital economy.

\section{Publisher:}

International Society of Applied Preventive Medicine i-gap

CSWHI 2020; 11(2): 12 - 18; DOI: 10.22359/cswhi_11_2_03 CC Clinical Social Work and Health Intervention

\section{Abstract:}

INTRODUCTION: Healthcare economy for hospital management is mandatory.

METHOD: Analytic study of essential data on hospital utilization in selected new EU member states is presented.

RESULTS: Trends in hospital rates, occupancy rates and screenings are closer to EU average within the last 20 years.

CONCLUSIONS: Certain goals, e.g. Occupancy rate $85 \%$ and increase of preventive screenings rate to $60 \%$ are highlighted. 


\section{Introduction}

New member states entering the EU during 2000-2004 (the V4 countries: SK, CZ, PL, HU; and ES, LT, LU) are required to match their healthcare to older EU member states by 2030 . In addition, a second group - the so called Balkan and South East Mediterranean countries - Malta, Cyprus, Romania, Bulgaria, Croatia (2005 2015) also are required to approach EU medical care levels by 2025 - 2035. (1-14) The goal of this analytic paper is to present the data of hospital utilization trends in a selected EU member state - SK.

\section{Method}

Longitudinal analysis and critical review of data/trends of healthcare attributes of the Hospital healthcare system, including occupancy rates, efficiency, screenings and other indicators has been performed from official and NGO sources in $2000-2020$.

\section{Results and Discussion:}

1 - Current Healthcare System: reflecting Demographics and Status Quo of the Slovak healthcare system is characterized by (i) Universal coverage; (ii) Competitive insurance model; (iii) Three health insurance companies (one stateowned and two private insurers); (iv) Ministry of Health sets standards for the healthcare system; (v) Health Care Surveillance Authority oversees health insurance, provisions and purchasing markets.

2 - Slovakia is a ,new" EU member state within V4. It has a population of 5.4 million with $46.2 \%$ of the population living in rural areas. Key Health Characteristics include: (i) Aging society; (ii) Low birth rates and immigration rates; (iii) Life expectancies lower than the EU - women 80.5 years, men 73.3 years.

3 - Healthcare in an Economic Framework. In 2014, health expenditures accounted for $7.9 \%$ of the GDP. The hospital debt and lack of investment reached $€ 3.9-€ 8.3$ billion below the EU average. Out-of-pocket payments comprise private expenditures. Inpatient services are funded by a diagnosis-related group system initiated in 2017. Outpatient services are funded by a capitation model.

\section{Demographics of SK}

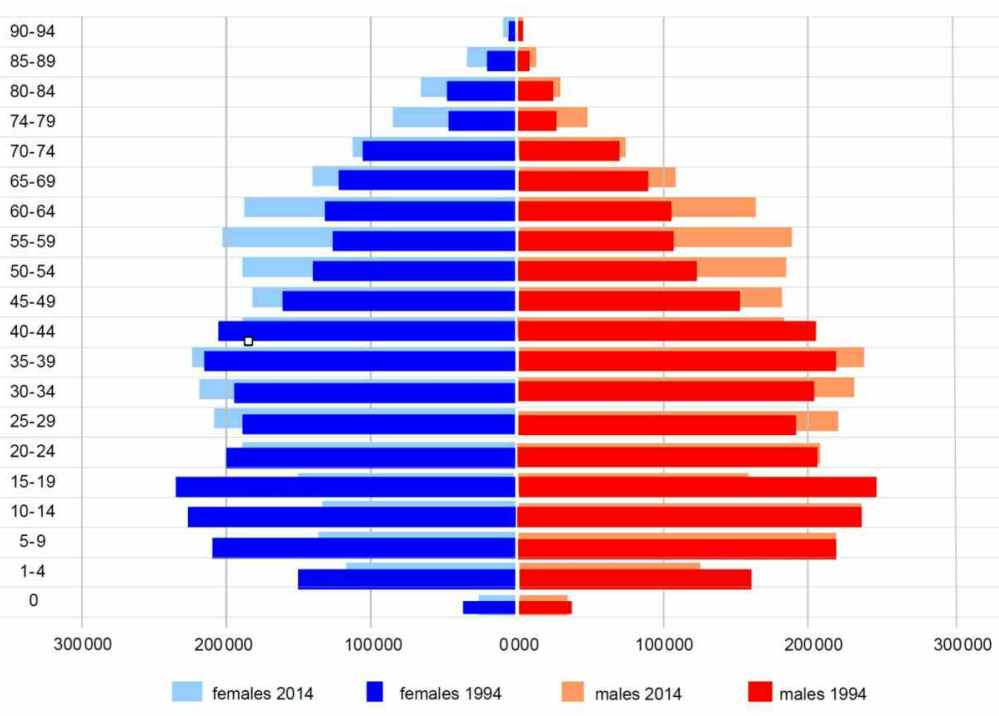

Healthcare reforms in $2004-2020$

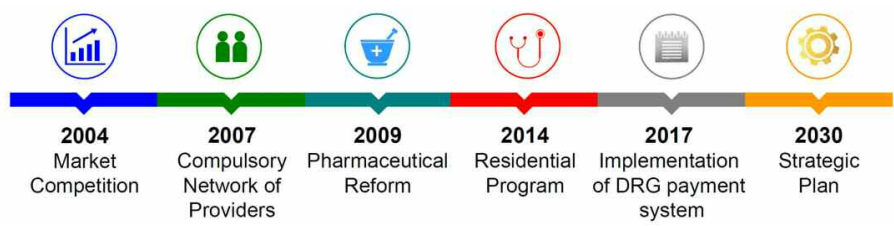


Hospital Expense \% of Total Healthcare Costs in 2010 - 2017

Comparison of AT, CZ, HU, PL, SK based on data from OECD (Organization for Economic and Co-Operation and Development, http//stats.oecd.org).

Note: cost increase for SK from $25 \%$ in 2010 to $32.7 \%$ in 2017 (see detailed numbers).

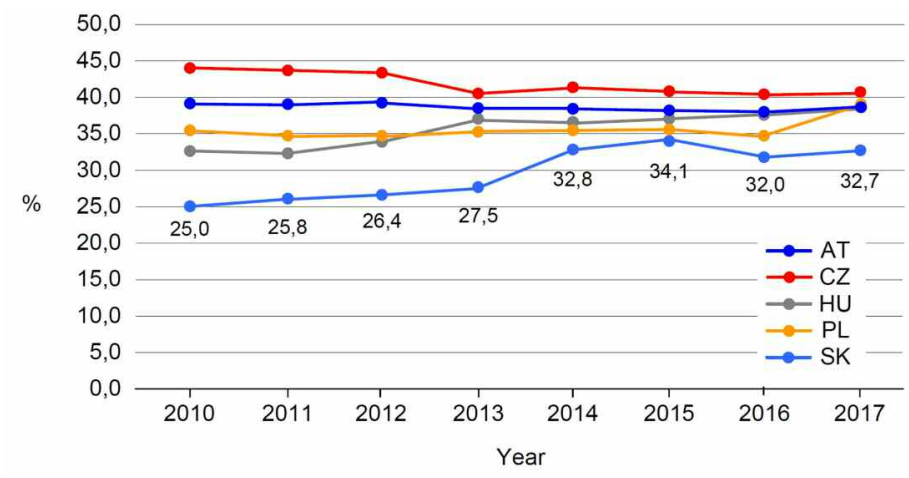

Comparison of V4 (SK, CZ, HU, $\mathrm{PL}$ ) plot based on data from [1]

Increase in non-communicable diseases is related partially to a higher life expectancy. Circulatory disease, cancer, diabetes mellitus and mental disorders are the leaders. Hospitals are operating with considerable liability deficits: (i) 2011 bail out; (ii) $€ 728$ Million debt for ministry hospitals; (iii) $0.1 \%$ point trend; (iv) Private Hospital systems moving into the country.

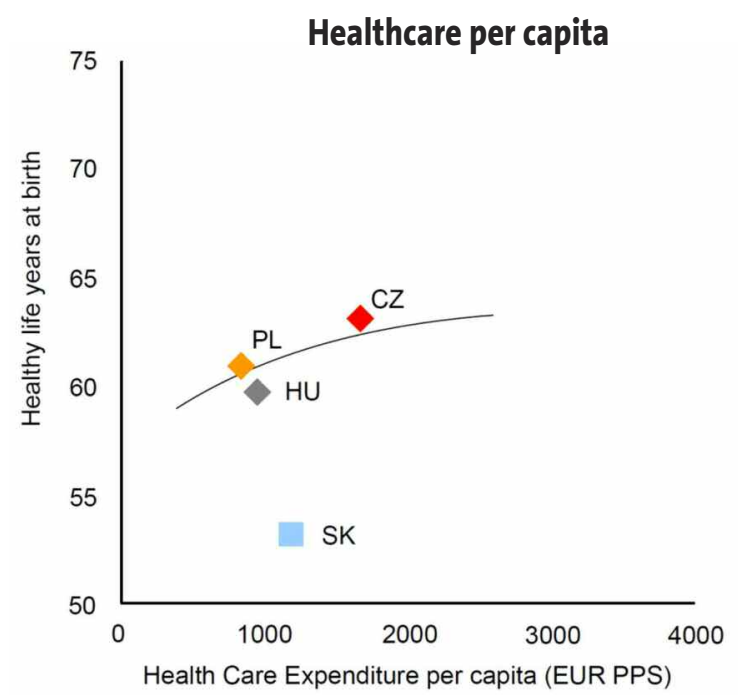

\section{Cost Effectiveness of SK healthcare system (plot based on data from [1])}

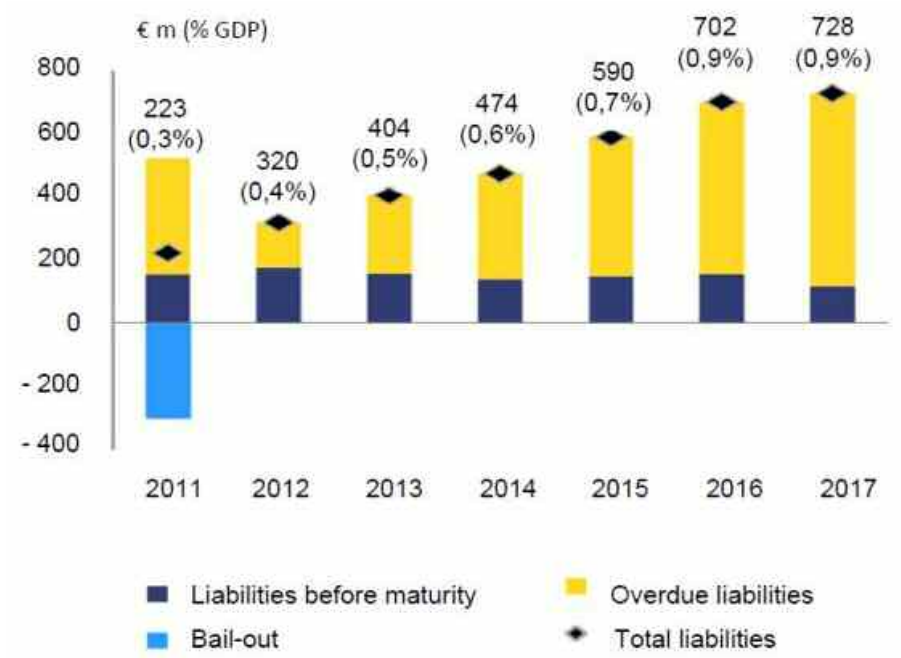


4-Healthcare trends: The number of hospitals per million population is decreasing. The total number of hospitals was reduced from 140 in 2010 to 134 in 2017 . Reduction in average length of stay is observed. The number of acute care beds decreased by $30 \%$ since $1990 \mathrm{~s}$ and is 4.2 beds $/ 1000$ persons. The goal by 2030 is to reduce acute care beds to $2.5 / 1000$ persons. The curative care occupancy is $67.8 \%$. The occupancy rates are decreasing and surplus of beds and facilities is noted. Outdated hospital infrastructure is of concern. The goal by 2030 is to reach an occupancy rate of $85 \%$. Lack of screening facilities and lengthy travel have been identified as key reasons for low screening rates. The goal by 2030 is to improve the rate of preventive screenings to $60 \%$.
Comparison of AT, CZ, HU, PL, SK based on data from OECD (Organization for Economic and Co-Operation and Development, http//stats. oecd.org).

Note: slight linear decrease for SK present/indicated.

Comparison of AT, CZ, HU, PL, SK based on data from OECD (Organization for Economic and Co-Operation and Development, http//stats. oecd.org).

Note: linear increase for SK present/indicated.
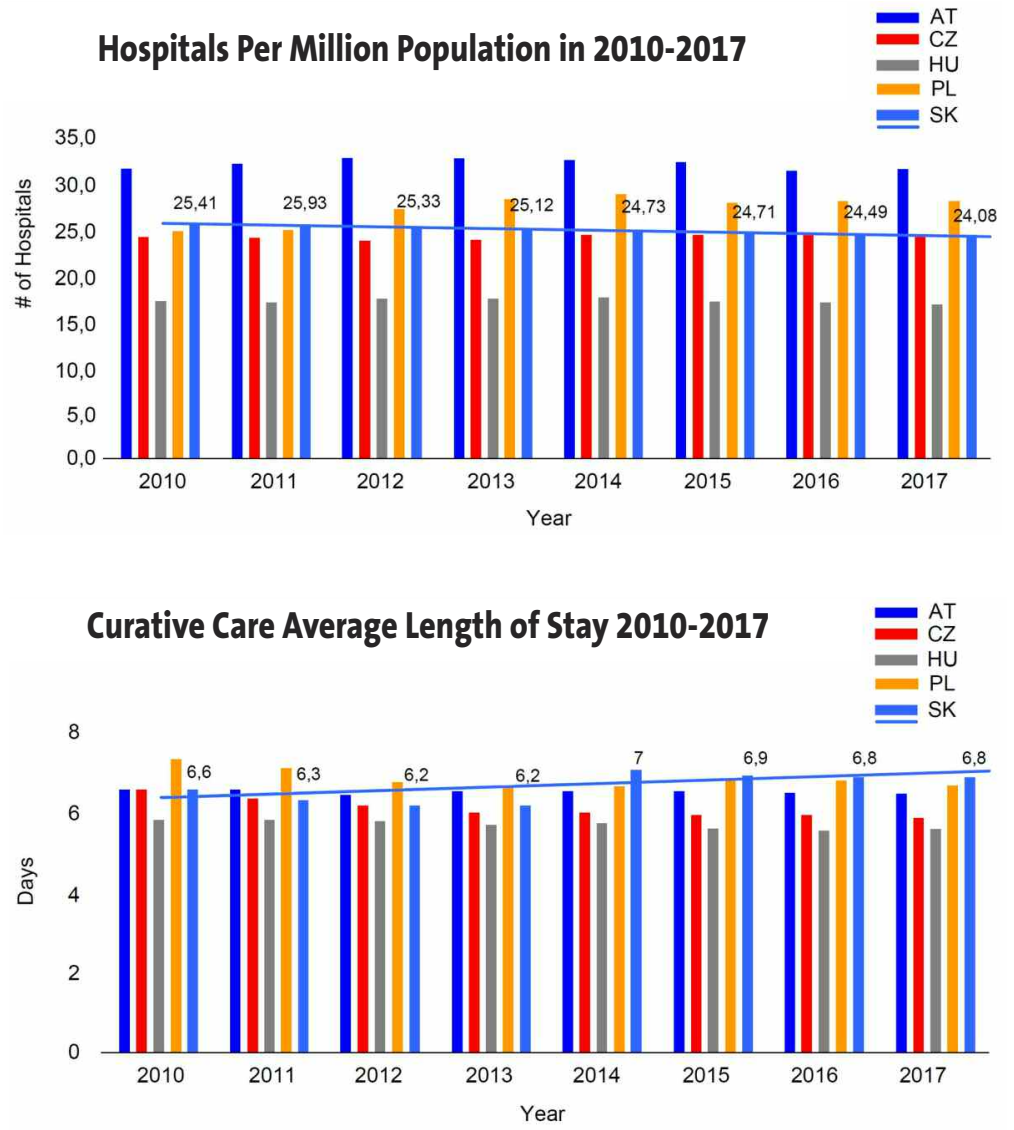

Comparison of AT, CZ, HU, PL, SK based on data from OECD (Organization for Economic and Co-Operation and Development, http//stats. oecd.org).

Note: slight linear decrease for SK present/indicated.

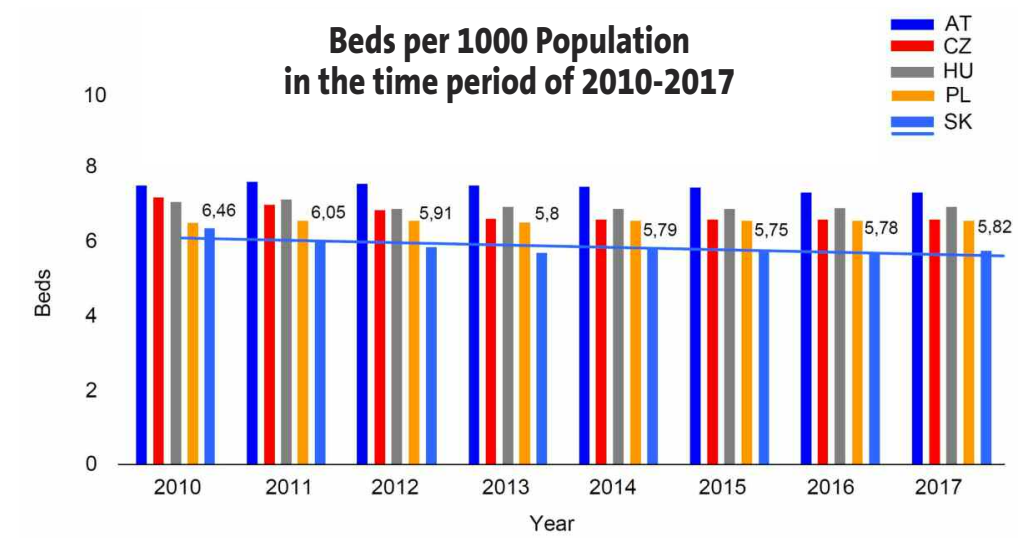


Comparison of AT, $\mathrm{CZ}, \mathrm{HU}, \mathrm{SK}$ based on data from OECD (Organization for Economic and Co-Operation and Development, http//stats. oecd.org).

Note: slight linear decrease for SK present/indicated.

Comparison of AT, $\mathrm{CZ}, \mathrm{HU}, \mathrm{SK}$ based on data from OECD (Organization for Economic and Co-Operation and Development, http//stats. oecd.org).

Note: slight linear increase for SK present/indicated.

Comparison of $\mathrm{CZ}$, HU, SK based on data from OECD (Organization for Economic and Co-Operation and Development, http//stats.oecd. org).

Note: slight linear decrease for SK present/indicated.

Comparison of $\mathrm{CZ}$, HU, SK based on data from OECD (Organization for Economic and Co-Operation and Development, http//stats.oecd. org).

Note: slight linear decrease for SK present/indicated.
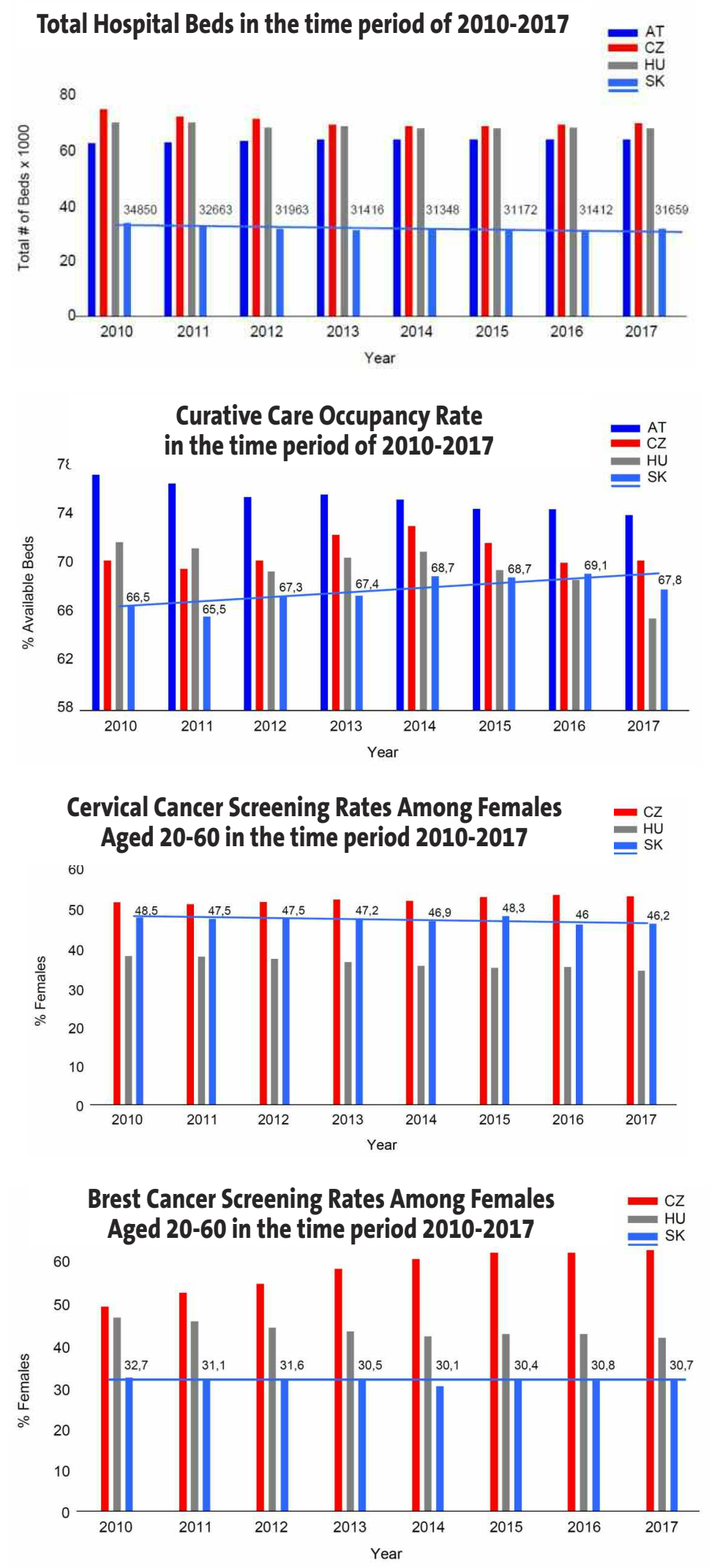


\section{Conclusions}

Strategic Plan Initiatives for 2030 include: (i) Reduce acute care beds to 2.5 per 1000 inhabitants; (ii) Increase occupancy rate to $85 \%$; (iii) Increase preventive screenings to $60 \%$; (iv) Empower General Physicians as gate keepers to reduce spending, (v) Convert inpatient hospital beds into long-term care beds to reduce inpatient spending and increase long term care revenues; (vi) Invest in hospital infrastructure; (vii) Continue to Reduce total number of hospitals and reduce curative care bed days.

\section{References:}

1. KUENZEL R, SOLANIC V (2018). Improving the Cost-Effectiviteness of Slovakia's Healthcare System. European Commission. Retrieved from https://ec.europa.eu/info/ sites/info/files/economy-finance/eb041_en_ $0 . p d f$.

2. ORGANIZATION FOR ECONOMIC AND CO-OPERATION DEVELOPMENT (2019) Retrieved from http://stats.oecd.org.

3. SMATANA M, PAZITNY P, KANDILAKI D, LAKTISOVA M, SEDLAKOVA D, PALUSKOVA E G, SPRANGER A (2016) Slovakia: Health System review, In: European Observatory on Health Systems and Policies. Vol. 18, No. 6.

4. STATE OF HEALTH IN THE EU: COUNTRY HEALTH PROFILE SLOVAK REPUBLIC 2017 (2017) European Observatory on Health Systems and Policies.

5. KIMULI D, KOMLOSI M, SABO I, BAUER F, KARVAJ M, OTRUBOVA J, JANCOVIC M, JANKECHOVA M, PAUEROVA K, POLONOVA K, MATEICKA F, BARTKOVJAK M, MIKOLASOVA G, SMREKOVA E, BENCA J, DURCOVA B, DORKO D, BEDNARIKOVA M, SCHIFFERDECKEROVA M, BARKASI D, OKOTH V, MULERA M (2019) Highlands malaria among internally displaced refugees in mountain areas of Kenya, Rwanda and Burundi. Lek Obz(Med Horizon)68.2019,5-6,149-150.

6. PROCHAZKOVA K, GREY E, MIKOLASOVA G, LIBOVA L, HUPKOVA I, PAUEROVA K, HOCHMAN R, JANCOVIC M, HOFBAUEROVA B, SRAMKOVA M, STANEKOVA P, BARTKOVJAK M, MURGOVAA, KATUNSKA M, TOMANEK P, MIK-
LOSKOVA M, MIKLOSKO J,VLCEK R, PALENIKOVA M, DRGOVA J, KOZON V, KONOSOVA H, HRINDOVA T, OTRUBOVA J (209) Analysis of 9896 Homeless Patients.Clin Soc.Work Health Intervention $10.2019,4$.

7. TOMANEK P, HARDY M, POLONOVA J, MIKLOSKOVA M, MIKOLASOVA G, BUCKO L, MRAZOVA M, KARVAJ M, JOBOVA M, VALLOVA J, HULKOVA V, BOZIK J, SLOVAK J, VLCEK R, BENCA J, SKOPOVA M, JANKECHOVA M, SHAHUM A (2017) St Louise Hospital for Marginalized and Homeless population. Clin Soc Work health Intervention,8,2017,1.13.

8. HAJ ALI P, PUTEKOVA S, KABATOVA J, MARTIKOVA J, ZOLLEROVA K, BUCKO L, RADKOVA, VLCEK R, GREY E, OLAH M, DURICOVA Z, SVITEK R, SIMONEK T, OTRUBOVA J, BIBZA M, KOLIBAB M, MAMOVA A, PALENIKOVA M, MURGOVA A, TKACOVA L, KALATOVA D, JANKECHOVA M, BYDZOVSKY J, KHALIL I, MICHALIKOVA L, MRAZOVA M, LISKOVA A, HERDICS G, CARNECKY M, KHALED I (2016) Are Migrants From Middle East Carriers of Resistant Bacteria. Clin Soc Work \& Health Intervention 7. 2016. 3,914.

9. KOVAC R, MIKLOSKOVA M (2013) The impact of early childhood to the risk of homelesness. Int.J.Prenat Perinat Psychol Med., 25.2013,S1,42.

10. KOZON V, ZACHAROVA E (2016) Stress as a risk factor in nurses.Clin Soc Work Health Intervention 7. 2016 .105.

11. HARDY M, BARTKOVJAK M, BERESOVA A, KNOSKOVA E, RADKOVA L, OTRUBOVA J, RABAROVA L, TOPOLSKA A, POLONOVA J, KALATOVA D, MIKOLASOVA G, PROCHAZKOVA K., STANKOVA P, MRAZOVA M, VALACH M, OLAH M, JACKULIKOVA M, DRGOVA J, PALENIKOVA M, BARKASI D, OTRUBOVA J, HOFBAUEROVA B, SCHIFFER DECKEROVA M, HATAPKOVA Z, KOVAC R (2019) Is the homeles shelter population a public Health Threat? Lek Obz (Med Horizon) 68, 2019, 4, 151-152.

12. SHAHUM A, SLADECKOVA V, BENCA J, DUDOVA Z, MIKLOSKOVA M, BIELO- 
VA M (2017) Respiratory islolates from the Orphanage in Phnompenh.,Clin Soc Work Health Intervention,8.2017,1,17.

13. HERDICS G, PROCHAZKOVA K, MIKOLASOVA G, MIKLOSKOVA M, OLAH M, KARVAJ M, OTRUBOVA J, BUCKO L,
RADKOVA L, TOMANEK P (2017) A daily low treshold shelter for the homeless population, Clin Soc Work health Intervention, 8.2017,1,11-13.

14. PUBLISHER LANCET. Child Nutrition. Lancet. 394. 2019, 1387. 